\title{
Some physicochemical and microscopic characteristics of Greek unifloral honeys
}

\author{
A Thrasyvoulou 1 , J Manikis 2 \\ 1 Laboratory of Apiculture-Sericulture, Aristotle University of Thessaloniki, 54006 Thessaloniki; \\ 2 Union of Beekeeping Associations of Northern Greece, Prometheus 6, 55134 Kalamaria, Greece
}

(Received 20 February 1995; accepted 16 May 1995)

\begin{abstract}
Summary - Water content, ash, HMF, diastase activity, electrical conductivity, $\mathrm{pH}$, proline and microscopic characteristics of 174 samples of unifloral honeys from thyme, chestnut, cotton, heather, orange, sunflower, pine and fir honeydew have been analysed. Differences among the corresponding values are given. The honeys from pine, fir, chestnut and heather have a high $\mathrm{pH}$, electrical conductivity and ash, but a low HMF. Thyme honey has high diastase and proline content where as orange honey shows the lowest values for $\mathrm{pH}$, proline, diastase activity, ash and electrical conductivity. Sunflower and cotton honeys have no distinct characteristics. Predominant pollen was found in thyme, sunflower, heather and chestnut honeys. More than 20 pollen types were found in pine and thyme honeys, 15-20 in fir, sunflower and heather and 10-15 in chestnut, cotton and orange honeys.
\end{abstract}

honey / unifloral / physicochemical characteristics / microscopic characteristics / Greece

\section{INTRODUCTION}

The annual honey production of Greece is estimated at 11000 tons. A large portion is derived from honeydews from pine and fir trees (Santas and Bikos, 1979).

Pine honey constitutes about $60 \%$ of the total annual honey production and is produced during autumn from honeydew secreted by the insect Marchalina hellenica (Gennadius), which is restricted to Pinus brutia Ten and $P$ halepensis Miller (Bodenheimer, 1953; Nikolopoulos, 1959; Kailidis, 1965). Another major honeydew honey is fir honey, which represents $5 \%$ of the total annual production. It is derived from honeydew produced by the insects Physokermes hemicryphus, Eulecanium sericeum and Mindarus abietinus, parasites on Abies cephalonica Loudon and $A$ borisiiregis Mattf, (Santas, 1983).

The large variety of melliferous sources also enables Greece to produce characteristic unifloral nectar honeys. The most wellknown is 'Hymettus honey', which has been famous since antiquity (Crane, 1979). This is a thyme honey which is mainly produced from Thymus capitatus $L, T$ serpyllum $L$ and 
Satureia spp. Thyme honey represents $10 \%$ of the total crop (Santas and Bikos, 1979). Heather, sunflower, orange and cotton honeys are also major Greek unifloral honeys that are produced in appreciable quantities which have not yet been estimated. Heather honey is produced mainly from Erica verticillata Forskal and $E$ carnea $L$ during autumn. While sunflower honey from Helianthus annuus $L$ is significant, it is produced in decreasing quantities because of the small monetary rewards associated with it. Cotton (Gossypium hirsutum L) and orange (Citrus spp) honeys, on the other hand, usually appear on the Greek market mixed with other blossom honeys. Finally, chestnut honey, which is produced from the nectar of Castanea sativa Mill, may be partly of honeydew origin because of the honeydew that is abundantly produced by the insect Myzocallis castanicola Baker (Santas, 1983).

The physicochemical characteristics of Greek unifloral honeys were partly examined by Kodounis (1962), Thrasyvoulou and Bladenopoulou (1984), Thrasyvoulou (1986), Bakandritsos et al (1993) and Thrasyvoulou and Manikis (1993). Most of the published material appears in Greek journals and is not easily accessible to the international scientific community. In this paper, we examine some characteristics of the major Greek nectar honeys to further contribute to the classification and characterization of European unifloral honeys.

\section{MATERIALS AND METHODS}

\section{Sampling}

Fresh samples of pine, fir, chestnut, thyme, sunflower, cotton, heather and orange honeys produced in different regions of Greece were collected from beekeepers between 1989 and 1993. Their classification as unifloral honey was based on their origin (information from beekeepers) and their organoleptic, microscopic and physicochemical characteristics. Samples that were doubtful in origin were excluded from the study. All samples were kept in a refrigerator until chemical analysis.

\section{Physicochemical analyses}

Water content, ash, HMF and diastase activity were measured as recommended by the Codex Alimentarius Commission (CAC, 1989).

The electrical conductivity was measured according to Louveaux et al (1973). The results are expressed in millisiemens/cm. The $\mathrm{pH}$ was measured in a $20 \%$ solution. Proline was estimated by using the method of Ough (1969) at $520 \mathrm{~nm}$, with the aid of a calibration curve obtained from solutions of pure dry proline. Ten samples of each category of honey were analysed for proline content.

\section{Melissopalynological analysis}

Melissopalynological analysis was carried out using the methods established by the International Commission of Bee Botany described by Louveaux et al (1978). Counts were expressed as percentages after counting $>600$ pollen grains. The ratio of honeydew elements to the number of pollen grains (HDE/P) was estimated in honeydew honeys by counting fungal spores, hyphae, algae and approximately 300 pollen grains. The frequency classes of pollen grains were given as predominant pollen $(>45 \%)$, secondary pollen $(16-45 \%)$, important minor pollen $(3-15 \%)$ and minor pollen (1-3\%.).

\section{RESULTS AND DISCUSSION}

\section{Physicochemical characteristics}

Table I shows the mean results and basic statistics obtained from the physicochemical analyses, the percentage of the main pollen in the unifloral honeys and the HDE/P ratio in the honeydew honeys. 


\section{Water content}

The majority of Greek honey was found to be low in moisture and therefore virtually safe from fermentation. Average moisture content $(16.8 \%)$ was $4.2 \%$ lower than the maximum allowable content for honey by the CAC (1989). The greatest values were also lower than the maximum permissible level of $21 \%$ with the exception of 2 samples of heather honey. Fir honey had the lowest moisture content (15.2\%) and heather the highest $(18.6 \%)$.

The average moisture content of Greek fir, thyme, heather, sunflower, chestnut and orange honeys $(16.8 \%)$ was lower than the corresponding value for Italian (17.3\%; Accorti et al, 1986) and French (17.6\%; Pourtallier and Taliercio, 1970) honeys. The distinct low water content of fir honey is in agreement with Accorti et al (1986).

The high water content for heather agrees with values reported in other countries (Spettoli et al, 1982; Accorti et al, 1986; Serra Bonvehi and Granados Tarres, 1993). Since the majority of heather honeys have high water content, the specification of $\mathrm{Cal}$ luna in the compositional standards for honey is not considered as necessary.

\section{$p H$}

Honey from orange trees had the lowest $\mathrm{pH}$, whereas pine, fir and chestnut honeys had the highest. Heather honey gave an average $\mathrm{pH}$, value of 4.2, placing it between flower honeys and honeydew.

The $\mathrm{pH}$ values of Greek unifloral honeys are in agreement with those found by Pourtallier and Taliercio (1970), Accorti et al (1986), Sabatier (1988), and Serra Bonvehi and Granados Tarres (1993), but not with those of Mohamed et al (1982) who found an average $\mathrm{pH}$ value of 6.2 in thyme honey.

\section{Electrical conductivity}

Honeydew and chestnut honeys had the highest conductivity while orange honey had the lowest. Sunflower and thyme honeys gave similar values; the same was found for heather and cotton honeys.

The high mean and wide range of electrical conductivity of chestnut honeys are noteworthy. Similar results were reported by Piazza et al $(1986,1991)$ who showed that nectar chestnut had honeydewlike characteristics (high $\mathrm{pH}$, ash and conductivity) but differed from honeydew honeys by its negative specific rotatory value. The conductivity of Greek heather honey agrees with that of the French (Pourtallier and Taliercio, 1970), Italian (Persano Oddo et al, 1988) and Spanish (Serra Bonvehi and Granados Tarres,1993) heather honeys.

\section{Ash}

The highest ash content was found in honeydew and chestnut honeys and the lowest in orange nectar honey. Two samples of fir honey $(12.5 \%)$ and all the chestnut honeys exceeded the maximum tolerance of the CAC standard. Such high ash content indicates an increased nutritional value of honey rather than adulteration (Feinberg, 1951).

The high values of $\mathrm{pH}$, ash, and electrical conductivity of Greek honeydew honeys are similar to data given for the average composition of honeydews from other countries (Kirkwood et al, 1960; White et al, 1962; Stefanini, 1984; Talpay, 1985; Accorti et al, 1986). These features can be used to distinguish between honeydew and blossom honeys as supplementary to their different microscopic and organoleptic characteristics. The low coefficient of variation (CV\%) of electrical conductivity of pine and 
Table I. Physicochemical characteristics of Greek unifloral honeys.

\begin{tabular}{|c|c|c|c|c|c|c|c|c|}
\hline \multirow[t]{2}{*}{ Botanical origin } & \multirow[b]{2}{*}{ Mean } & \multicolumn{3}{|c|}{ Moisture (\%) } & \multicolumn{4}{|c|}{$p H$} \\
\hline & & $S D$ & $\mathrm{~V}_{\min }$ & $\mathrm{V}_{\max }$ & Mean & $S D$ & $\mathrm{~V}_{\min }$ & $\mathrm{V}_{\text {max }}$ \\
\hline Pine & 16.6 & 1.06 & 14.9 & 18.9 & 4.8 & 0.21 & 4.5 & 5.4 \\
\hline Fir & 15.2 & 1.54 & 13.0 & 18.5 & 5.0 & 0.26 & 4.7 & 5.9 \\
\hline Chestnut & 16.3 & 0.71 & 14.9 & 17.4 & 4.9 & 0.19 & 4.6 & 5.4 \\
\hline Thyme & 16.1 & 0.51 & 15.4 & 17.0 & 3.7 & 0.12 & 3.5 & 4.1 \\
\hline Cotton & 17.9 & 0.93 & 16.8 & 19.8 & 3.9 & 0.16 & 3.7 & 4.3 \\
\hline Sunflower & 17.4 & 0.84 & 16.5 & 19.5 & 3.8 & 0.12 & 3.6 & 4.0 \\
\hline Orange & 16.9 & 0.66 & 16.0 & 18.5 & 3.4 & 0.05 & 3.3 & 3.6 \\
\hline Erica & 18.6 & 2.19 & 16.0 & 23.0 & 4.2 & 0.27 & 3.3 & 4.6 \\
\hline \multirow[t]{2}{*}{ Botanical origin } & \multicolumn{4}{|c|}{ Conductivity $\left(\mathrm{mS} . \mathrm{cm}^{-1}\right)$} & & \multicolumn{2}{|c|}{ Ash (\%) } & \\
\hline & Mean & $S D$ & $\mathrm{~V}_{\min }$ & $\mathrm{V}_{\max }$ & Mean & $S D$ & $\mathrm{~V}_{\min }$ & $\mathrm{V}_{\text {max }}$ \\
\hline Pine & 1.26 & 0.12 & 1.01 & 1.47 & 0.6 & 0.03 & 0.4 & 0.7 \\
\hline Fir & 1.40 & 0.19 & 1.01 & 1.69 & 0.9 & 0.12 & 0.5 & 1.1 \\
\hline Chestnut & 1.54 & 0.32 & 1.11 & 2.06 & 0.8 & 0.15 & 0.6 & 1.2 \\
\hline Thyme & 0.42 & 0.94 & 0.25 & 0.52 & 0.2 & 0.12 & 0.1 & 0.5 \\
\hline Cotton & 0.60 & 0.98 & 0.45 & 0.76 & 0.2 & 0.15 & 0.1 & 0.5 \\
\hline Sunflower & 0.43 & 0.12 & 0.26 & 0.57 & 0.2 & 0.11 & 0.1 & 0.3 \\
\hline Orange & 0.19 & 0.38 & 0.15 & 0.31 & 0.1 & 0.05 & 0.1 & 0.2 \\
\hline Erica & 0.67 & 0.16 & 0.56 & 0.89 & 0.4 & 0.11 & 0.3 & 0.6 \\
\hline
\end{tabular}

fir honeys ( 11.5 and $13.5 \%$ respectively) indicates uniformity, which confirms the view that conductivity is a characteristic of the plant species from which the honey is derived, and is not influenced by differences in the weather, year of harvest or geographical origin (Vorwohl, 1964). The correlation coefficient ( $r$ ) of the relationship between ash and electrical conductivity of the different types of Greek unifloral honey was more than 0.97 except in chestnut honey, where it was 0.41 . High linear relationships between the 2 parameters were found by Accorti et al (1987), Piazza et al (1991), Sancho et al (1991) and Bianchi (1992).

\section{HMF}

The HMF content is a criterion of the freshness and heat processing of honey. Fresh honey may contain small amounts of HMF (White,1979), which rarely exceed $10 \mathrm{mg} / \mathrm{kg}$ (Rodgers, 1979). The averages and maximum values $\left(V_{\max }\right)$ of our samples are smaller than this figure, except for heather and orange honey which had one sample with 11.9 and $10.7 \mathrm{mg} / \mathrm{kg} \mathrm{HMF}$, respectively. Uncommonly high HMF was also found in Italian heather honey (Accorti et al, 1986; Persano Oddo et al, 1988). Fir and pine honeys have the lowest HMF values, 
Table I. Continued.

\begin{tabular}{|c|c|c|c|c|c|c|c|c|}
\hline \multirow[t]{2}{*}{ Botanical origin } & \multicolumn{4}{|c|}{$H M F(m g / k g)$} & \multicolumn{4}{|c|}{ Diastase (DU) } \\
\hline & Mean & $S D$ & $\mathrm{~V}_{\min }$ & $\mathrm{V}_{\max }$ & Mean & $S D$ & $\mathrm{~V}_{\min }$ & $\mathrm{V}_{\max }$ \\
\hline Pine & 2.7 & 2.88 & 0.0 & 8.2 & 28.4 & 2.20 & 15.1 & 37.2 \\
\hline Fir & 2.1 & 1.41 & 0.7 & 3.8 & 18.5 & 5.46 & 10.4 & 29.6 \\
\hline Chestnut & 4.5 & 1.80 & 1.7 & 8.2 & 32.2 & 8.91 & 23.9 & 51.0 \\
\hline Thyme & 5.6 & 1.96 & 2.1 & 8.6 & 32.5 & 8.61 & 15.1 & 48.2 \\
\hline Cotton & 5.8 & 1.67 & 2.4 & 9.2 & 17.6 & 4.18 & 10.2 & 27.0 \\
\hline Sunflower & 4.8 & 1.78 & 1.1 & 7.9 & 15.9 & 3.17 & 9.3 & 23.0 \\
\hline Orange & 5.6 & 2.53 & 2.5 & 10.7 & 11.7 & 3.78 & 8.6 & 15.5 \\
\hline Erica & 4.3 & 3.20 & 0.0 & 11.9 & 27.6 & 5.33 & 17.9 & 32.1 \\
\hline
\end{tabular}

Botanical origin

Proline $(\mathrm{mg} / \mathrm{kg})$

$H D E / P$ a , pollen $(\%)^{\mathrm{b}}$

\begin{tabular}{|c|c|c|c|c|c|c|c|c|}
\hline & & & \multirow{2}{*}{$\mathrm{v}_{\max }$} \\
\hline & Mean & $S D$ & $\mathrm{~V}_{\min }$ & $\mathrm{V}_{\max }$ & Mean & $S D$ & $\mathrm{~V}_{\min }$ & \\
\hline Pine & 514 & 260 & 324 & 673 & $0.26^{a}$ & $0.23^{a}$ & $0.05^{a}$ & $0.90^{\mathrm{a}}$ \\
\hline Fir & 390 & 194 & 290 & 580 & $0.70^{\mathrm{a}}$ & $1.20 \mathrm{a}$ & $0.13^{a}$ & $1.43^{a}$ \\
\hline Chestnut & 554 & 139 & 432 & 734 & $90.4^{b}$ & $3.3^{b}$ & $85.0^{b}$ & $95.0^{\mathrm{b}}$ \\
\hline Thyme & 790 & 232 & 596 & 1205 & $48.7^{b}$ & $15.8^{b}$ & $35.0^{\mathrm{b}}$ & $85.1^{\mathrm{b}}$ \\
\hline Cotton & 432 & 103 & 305 & 650 & $38.3^{b}$ & $13.4^{b}$ & $20.0^{b}$ & $45.0^{\mathrm{b}}$ \\
\hline Sunflower & 665 & 352 & 298 & 1199 & $40.5^{b}$ & $17.7^{b}$ & $21.1^{b}$ & $81.1^{b}$ \\
\hline Orange & 326 & 134 & 264 & 636 & $9.6^{b}$ & $1.8^{\mathrm{b}}$ & $7.6^{b}$ & $14.1^{\mathrm{b}}$ \\
\hline Erica & 536 & 332 & 329 & 931 & $63.3^{b}$ & $15.6^{b}$ & $45.0^{\mathrm{b}}$ & $90.0^{\mathrm{b}}$ \\
\hline
\end{tabular}

Number of samples: pine 48 , fir 16 , chestnut 13 , thyme 20 , sunflower 20 , cotton 20 , heather 20 , orange 17 . Ten samples from each category for proline. a HDE/ $P$ for pine and fir honeys and $b \%$ pollen for other unifloral honeys.

whereas sunflower, orange, thyme and cotton honeys have the highest.

\section{Diastase activity}

The diastase activity (expressed in diastase units, DU) of all 174 samples examined averaged at 23.0 and ranged from a minimum of $8.6 \mathrm{DU}$ (orange) to a maximum of $51 \mathrm{DU}$ (chestnut). Thymus and chestnut honeys had high values, heather and pine moderate, whereas sunflower, cotton and fir honeys had a low diastase activity. Finally orange honey had the lowest diastatic value.

In a previous study, an average diastase activity of 15.6 DU for thyme honey with the minimum value of $4.5 \mathrm{DU}$ was recorded (Thrasyvoulou, 1986), which was contradictory to the high diastase activity of 33.1 DU of Italian thyme honey (Persano Oddo et al, 1990). We investigated the possibility of whether beekeeping techniques might have 
affected the enzymes of this honey. We found that in certain dry, hot islands, beekeepers feed bees with substantial amounts of syrup to maintain a high bee population. This decreased diastase activity was previously demonstrated by Zalewski (1962), Kuznetsov and Ermolaeva (1964), Popescu et al (1965), and Zagaevskll and Kramarenko (1982). The samples examined in this research had been collected from beekeepers that fed no sugar syrup to their bees during the spring. The average diastase activity of those samples (32.2) was closer to the corresponding values for Italian honeys.

Comparison of our results of diastase activity with those previously reported in the literature, shows that the values for the Greek sunflower and orange honeys (15.9 and 11.7) correspond to those reported by Persano Oddo et al (1990) for Italian honeys (16.3 and 9.8). However, they do not agree with the 21.8 DU value of orange found in Spanish honeys (Serra Bonvehi and Gomez Pajuero, 1983). The value of Greek heather honey (27.6) was higher than the Italian value (7.8). The DU value in fir (18.5) was similar to the Italian (22.9) (Persano Oddo et al, 1990) and lower than the French honeys (43.0) (Pourtallier and Taliercio, 1970).

The wide range of diastase activity observed in thyme (33.1) and in chestnut honeys (27.1) is not unusual in unifloral honeys. Rusakova (1984) found a range of $\mathbf{3 0 . 7}$ for lime honey, Persano Oddo et al (1990) found 32.3 for chestnut and 23.2 DU for Italian fir honey, and Serra Bonvehi and Granados Tarres (1993) found 55 DU for heather honey. This natural variation and the differences between the same types of honeys produced in different countries was the reason for a severe criticism of the use of diastase as a criterion of quality evaluation of honey (Schade et al, 1958; Wilson,1971; Rusakova 1984; Thrasyvoulou, 1986; Kim, 1987; White 1992).

\section{Proline}

The proline content of the 80 samples taken from the 8 different unifloral honeys was found to have an average of $526 \mathrm{mg} / \mathrm{kg}$, with a minimum value of 264 in orange and a maximum of 1205 in thyme (table I). Thyme and sunflower honeys had high amounts of proline whereas orange and fir honeys had the lowest content.

Proline can be used to distinguish genuine from adulterated honey, since honey from sugar-fed bees has significantly lower levels of proline. No sample was found to contain proline near to the $160-200 \mathrm{mg} / \mathrm{kg}$ indicator level for honey adulteration (White and Rudyj, 1978; Talpay 1985; Dustmann, 1993).

\section{Microscopic characteristics}

Predominant pollen was found in the thyme, sunflower, heather and chestnut samples (table I). Pine and fir honey had a low HDE/P ratio that did not agree with the high value ( $>3$ ) of honeydews from other countries (Louveaux et al, 1978). The presence of large fungal spores that characterized the Greek pine honey (Sawyer, 1988) was not so common in our samples.

The number of pollen types in Greek unifloral honeys varied from 24 to 10 (table II). High numbers of pollen types ( $>20$ ) were found in pine, and thyme honeys, medium number (15-20) in fir, sunflower and heather honeys and low (10-15) in chestnut, cotton and orange honeys. As the pollen grains with a frequency $<1 \%$ were not identified, and not all the pollen grains could be identified to species level, our results are not directly comparable with the results of other authors. The average number of pollen types in Greek honeys does not essentially differ from those reported by Varis et al (1982) and Seijo et al (1992), but are smaller than those recorded by Serra Bonvehi and Mundo Elias (1988) and Jato et al (1991). 
छे

兽望 $\stackrel{1}{\stackrel{\leftrightarrow}{g}}$ 妾 㐘

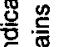
ळे

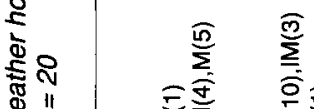

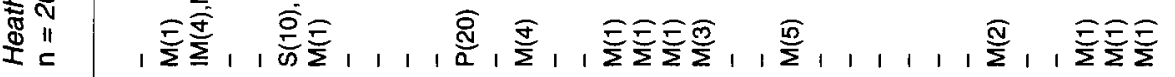
ळ

요요 $\hat{0}$

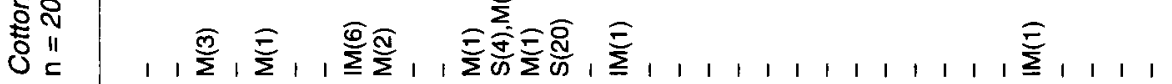

बे

ఫे

$\stackrel{0}{\varepsilon}$

ह

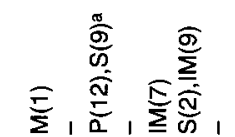

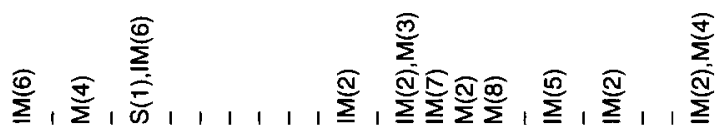

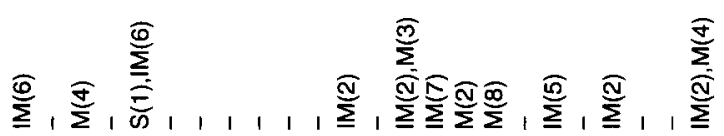

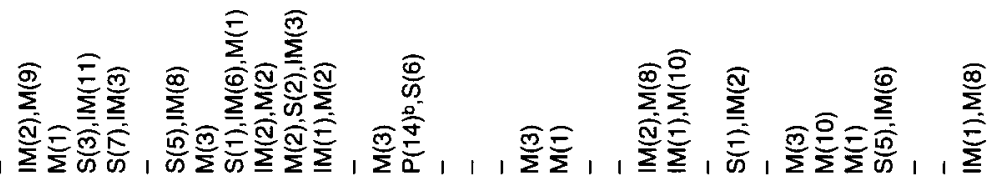
ஓे

$\oint^{8}$

点

屯

के

$\stackrel{g}{\infty}$

it

$\stackrel{\text { के }}{\frac{2}{5}}$

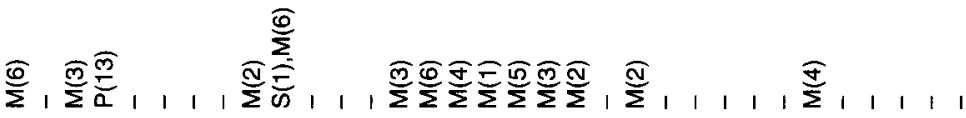

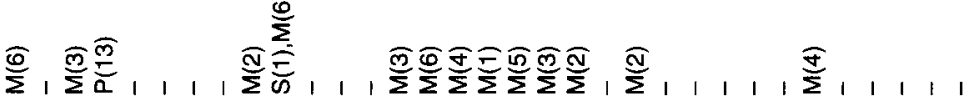

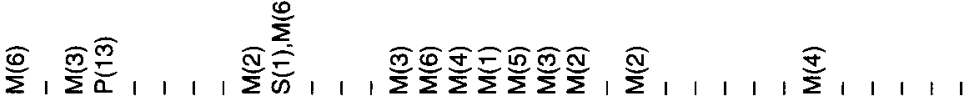

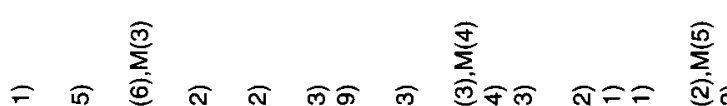

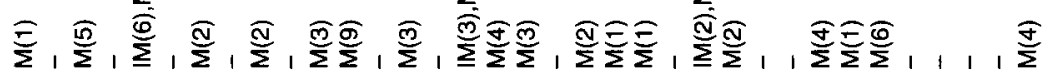

要

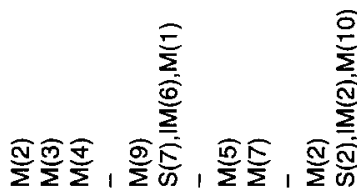

을

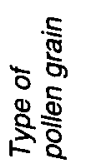

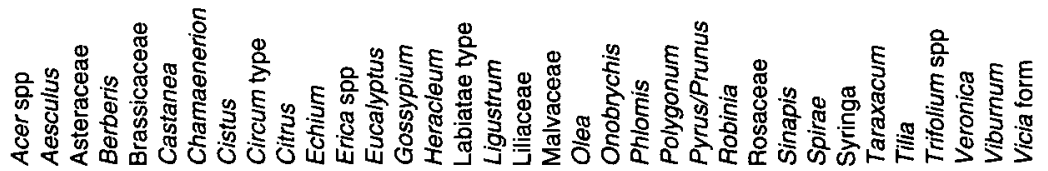


The great number of different pollen types in pine honey may be explained by contamination with foreign pollen. Pollen that had been collected and stored by bees in combs near brood area during the spring is totally sealed with pine honey during the heavy honeydew flow. These combs may be extracted 2 or more times by the beekeepers resulting in contamination of pine honey with foreign pollen. Floral honey produced in the colonies before their removal to pine forest could cause a secondary pollen contamination.

From the pollen spectrum of Greek unifloral honeys in table II, we can conclude the following:

\section{Pine and fir honeys}

Secondary and important minor pollen in pine honey were usually of chestnut and heather. The rest were different minor pollen. Important minor pollen grains in fir honey were those of Brassicaceae, Labiatae and Pyrus/Prunus. Erica spp appeared in 9 of the 16 samples of fir honey in minor frequency.

\section{Chestnut honey}

The pollen grains of chestnut were overrepresented as expected (Louveaux et al, 1978). The average percentage of pollen grains of Castanea was $90.4 \pm 4.5 \%$ and the maximum $95 \%$. Four samples with between 85 and $90 \%$ pollen grains of Castanea were regarded as being produced from Castanea plant, since they had the chemical and organoleptic characteristics of chestnut honey. Other important pollen grains were not found.

\section{Thyme honey}

Fourteen samples of thyme honey out of 20 were found with Thymus as predominant pollen (45-85.1\%) and 6 as secondary pollen (35-45\%). Samples with less than $35 \%$ were rejected. The minimum percentage of Thymus-type pollen in the rejected samples was $7.8 \%$. The pollen grains of Castanea, Cistus, Citrus, Compositae, Brasicaceae, Erica spp, Prunus/Pyrus, Robinia, Taraxacum, Trifolium spp and Vicia form appear in more than half of the thyme samples, although in different frequencies.

\section{Sunflower honey}

Although the pollen grains of sunflower are under-represented (Sawyer, 1988), we found a range of 21.1 to $81.17 \%$ pollen grains of Helianthus. Twelve samples $(57.2 \%)$ were found with predominant and $9(42.8 \%)$ with secondary pollen. Castanea was the most frequently found pollen type apart from Helianthus in sunflower honeys.

\section{Cotton honey}

Talpay (1985) cited honeydew of cotton as containing Gossypium only as minor pollen. We found a range between 3 and $45 \%$ for pollen grains of Gossypium in samples examined as cotton honey. Samples that had percentages of pollen grains of Gossypium less than $20 \%$ were rejected. Cotton honey is not listed by the International Commission for Bee Botany as being under-represented in pollen of the plant origin (Louveaux et al, 1978). Erica spp was the most frequent pollen grain in cotton honey.

\section{Heather honey}

The pollen of Erica spp was predominant in all samples that were examined and occasionally reached $90 \%$. Important minor and minor pollens were rare and were mainly those of Castanea. 


\section{Orange honey}

Citrus pollen was found in the range of 7.3 to $14.1 \%$. Brassicaceae, Erica spp and Trifolium spp were the most frequent pollen types that appeared in orange honey.

\section{CONCLUSIONS}

This research describes the variability of the physicochemical parameters of 8 Greek unifloral honeys. The high electrical conductivity, ash and $\mathrm{pH}$ of pine, fir and chestnut honeys are the only variables among those examined with actual diagnostic potential. The averages of the other parameters differed between unifloral honeys but were not representative and do not characterize a certain type of honey. Thyme and chestnut honeys are richer in diastase activity, whereas orange honey is low in $\mathrm{pH}$, ash, proline, diastase and electrical conductivity. Sunflower honey, on the other hand, has a high content of proline but low diastase. Heather honey may have water content that exceeds the maximum permissible level of $21 \%$. Futhermore, all the chestnut samples do not comply with CAC standards for ash content. Pollen analysis along with the physicochemical and organoleptic parameters can be very useful to characterize unifloral honeys, especially those derived from thyme, sunflower, heather and chestnut blossom.

\section{ACKNOWLEDGMENTS}

We are grateful to Greek beekeepers that collaborated with us in providing samples of honey and valuable information. We also wish to thank the students of the Agricultural Faculty, Aristotelian University of Thessaloniki, particularly $S$ Befa, E Koutis, T Loulou, C Makris, M Dandali, and $\mathrm{H}$ Tomproukidou for their technical assistance. The valuable suggestions and advice of 2 referees are acknowledged.
Résumé - Quelques caractéristiques physico-chimiques et microscopiques de miels grecs unifloraux. Au total, 174 échantillons de miels unifloraux ont été analysés : pin $(n=48)$, sapin $(n=16)$, châtaignier $(n=13)$, thym $(n=20)$, bruyère $(n=$ $20)$, oranger $(n=17)$, tournesol $(n=20)$ et coton $(n=20)$. On a déterminé la teneur en eau, en cendres, en HMF, en proline, l'activité enzymatique, la conductibilité électrique, le $\mathrm{pH}$ et les caractéristiques microscopiques. Tous les échantillons étaient frais, non traités et stockés au réfrigérateur au préalable. Les teneurs en eau, en cendres, en HMF ont été mesurées selon les recommandations de la CAC (1989), la teneur en proline selon Ough (1969), la conductibilité électrique selon Louveaux et al (1973), et l'analyse mélissopalynologique selon Louveaux et al (1978). Le tableau I présente les principaux résultats des analyses physico-chimiques, le pourcentage du pollen principal des miels unifloraux et le rapport HDE/P dans les miellats. Le tableau II présente les résultats des analyses polliniques. Les classes de fréquence des grains de pollen se répartissent en : prédominant $(P)$, secondaire (S), mineur important (IM) et mineur (M). La majorité des miels avait une faible teneur en eau (en moyenne $16,7 \%$ ). Les valeurs maximales étaient inférieures à ce qui est autorisé par la CAC $(21 \%)$. Le miel de bruyère présentait la valeur moyenne la plus élevée $(18,6 \%$ ) (2 échantillons avaient une humidité supérieure à $21 \%$ ), tandis que le miel de sapin avait la plus basse $(15,2 \%)$. Les miels de pin, de sapin et de châtaignier avaient les valeurs les plus élevées pour le $\mathrm{pH}$, la teneur en cendres et la conductibilité électrique, tandis que le miel d'oranger avait les plus basses. Tous les échantillons de miels de châtaignier et 2 de sapin dépassaient la tolérance maximale en cendres fixée par la CAC. Une corrélation significative a été observée entre la teneur en cendres et la conductibilité électrique $(r>0,97)$. Pour le miel de châtaignier, la relation n'était pas linéaire $(r=0,41)$. 
L'activité enzymatique était élevée pour les miels de thym et de châtaignier (respectivement 32,5 et 32,2 ), modérée pour les miels de pin et de bruyère $(28,4$ et 28,6$)$, basse pour les miels de sapin, de coton et de tournesol $(18,5,17,6,15,9)$ et très basse pour le miel d'oranger $(11,7)$. Les miels de thym et de tournesol avaient une teneur en proline plus élevée que les autres miels unifloraux. La valeur minimale de $264 \mathrm{mg}$ de proline par $\mathrm{kg}$ de miel qui a été trouvée dans un échantillon de miel d'oranger était supérieure au taux minimum caractéristique d'une altération du miel. Les miels de thym et de pin comportaient plus de 20 types différents de pollen, les miels de sapin, tournesol et bruyère entre 15 et 20 , les miels de châtaignier, de coton et d'oranger entre 10 et 15. Le pollen prédominant a été trouvé dans les miels de châtaignier, de thym, de tournesol et de bruyère. Le pollen de bruyère a été le pollen le plus fréquent dans les miels grecs unifloraux.

miel unifloral / caractéristiques physicochimiques et microscopiques / Grèce

\section{Zusammenfassung - Einige physika- lisch-chemische und mikroskopische} Eigenschaften von griechischen Sortenhonigen. Wassergehalt, Asche, HMF, Diastaseaktivität, elektrische Leitfähigkeit, $\mathrm{pH}$, Prolin und mikroskopische Eigenschaften von 174 Proben verschiedener Sortenhonige wurde analytisch bestimmt. 48 Honigproben stammten von Pinien, 16 von Tannen, 13 von Edelkastanien, 20 von Thymian, 20 von Heide, 17 von Orangen, 20 von Sonnenblumen und 20 von Baumwolle. Die frischen, nicht bearbeiteten Proben wurden im Kühlschrank bis zur Analyse aufbewahrt. Wassergehalt, Asche, HMF und Diastaseaktivität wurden entsprechend der Empfehlungen von CAC (1989) bestimmt. Die Messung der elektrischen Leittähigkeit wurde mit Methoden von Louveaux et al (1973), die von Prolin mit denen von Ough
(1969) und die Pollenanalyse nach Louveaux et al (1978) durchgeführt. Tabelle I gibt die mittleren Werte und statistische Angaben der physikalisch-chemischen Analysen, sowie den Prozentsatz des Hauptpollenanteils im Sortenhonig und das HDE/P Verhältnis im Honigtauhonig wieder. Tabelle II zeigt die Pollenanalyse von griechischen Sortenhonigen. Die Frequenzklassen der Pollenkörner wurden als vorherrschend $(P)$, zweitrangig (S), als wichtige Nebenpollen (IM) und unbedeutende Pollen (M) angegeben. Die meisten griechischen Honige hatten einen geringen Wassergehalt (im Durchschnitt 16,7\%). Fast alle Werte waren geringer als das Maximum des nach CAC erlaubten Wassergehaltes (21\%); 2 Proben des Heidehonigs hatte über $21 \%$. Tannenhonig hatte mit $15,2 \%$ den niedrigsten und Heidehonig mit 18,6\% den höchsten Wassergehalt. Die Werte des $\mathrm{pH}$, der Asche und der elektrischen Leitfähigkeit waren bei Pinien-, Tannen- und Edelkastanienhonig am höchsten, während sie beim Orangenhonig am niedrigsten waren. Alle Proben der Edelkastanie und 2 der Tanne (12,5\%) überschritten bei den Aschewerten die Toleranzgrenze nach CAC (1989). Es wurde ein signifikanter Zusammenhang $(r>0,97)$ zwischen Asche und elektrischer Leitfähigkeit gefunden. Nur im Edelkastanienhonig gab es keinen linearen Zusammenhang ( $r=$ 0,41 ). Die Diastaseaktivität war in Honigen von Thymian $(32,5)$ und Edelkastanien $(32,2)$ hoch, von Pinien und Heide $(28,4$ bzw 27,6) mäßig. Bei Tanne, Baumwolle und Sonnenblumen war sie niedrig $(18,5$, 17,6 und 15,9) und sehr niedrig im Orangenhonig $(11,7)$. Thymian- und Sonnenblumenhonige hatten einen signifikant höheren Prolingehalt als die anderen Sortenhonige. Der niedrigste Wert, der mit $264 \mathrm{mg}$ Prolin $/ \mathrm{kg}$ Honig in einer Probe von Orangenhonig gemessen wurde, lag noch weit über der Grenze (160-200 mg), die als Indikator für eine Verfälschung gilt. Pinienund Thymianhonige enthielten mehr als 20 unterschiedliche Pollenarten, Tanne, Son- 
nenblumen und Heidehonige 15-20, Edelkastanien-, Baumwoll- und Orangenhonig 10-15. Vorherrschende Pollenarten wurden in Honigen von Edelkastanien, Thymian, Sonnenblumen und Heide gefunden. Heidepollen war der in griechischen Sortenhonigen am häufigsten gefundene Pollen.

\section{Honig / Sortenhonig / physikalisch-che- mische und mikroskopische Eigen- schaften / Griechenland}

\section{REFERENCES}

Accorti M, Persano Oddo L, Piazza MG, Sabatini AG (1986) Schede di caratterizzazione delle principali qualità di miele uniflorale italiano. Apicoltura 2, appendice, $36 \mathrm{p}$

Accorti M, Piazza MG, Persano Oddo L (1987) La conductivité électrique et le contenu en cendre du miel. Apiacta XXII, 19-20

Bakandritsos N, Mallios I, Zoutsou P, Manatos N (1993) Physico-chemical parameters of Greek honey. $I n$ : Proc National Conferences of Greece about Honey, Gerakini Chalkidiki, 139-164 (in Greek)

Bianchi EM (1992) Determining the mineral (ash\%) content in honey by conductometric analysis. Apiacta VII, 19-24

Bodenheimer FS (1953) The Coccoidea of Turkey. III. Instanbul Univ Fac Sci Rev Ser B, 17, 91-164

Codex Alimentarius Commission (1989) Codex standard for honey (worldwide standard). FAO-WHO, CAC Vol 3, Ed 1 Supp 2, Rome

Crane $E$ (1979) The flowers honey comes from. In: Honey, A Comprehensive Survey (E Crane, ed), Heinemann, London, 3-76

Dustmann JH (1993) Honey, quality and its control. Am Bee $J 133,648-651$

Feinberg B (1951) Ash in honey. Am Bee J91, 471

Jato MV, Sala-Llinares A, Iglesias MI, Suarez-Cervera M (1991) Pollens of honeys from north-western Spain. $J$ Apic Res 30, 69-73

Kailidis DS (1965) Monophiebus hellenicus (= Marchalina hellenica) Genn. The pine insect feeder of honey bees. Dasika Chronika 81-82, 305-321 (in Greek)

Kim JK (1987) Variation and alterations in the chemical composition, diastase number and HMF content of Korean honeys. Korean J Apic 2, 9-66

Kirkwood KC, Mitchell TJ, Smith D (1960) An examination of the occurrence of honeydew in honey. Analyst $85,412-416$
Kodounis Ml (1962) The crystallisation of honey. PhD Thesis, Higher School of Agriculture, University of Athens, $88 \mathrm{p}$ (in Greek)

Kuznetsov VA, Ermolaeva PE (1964) The problem of adulteration of honey in the markets of Ashkhabad. Trudy Turkman Sel Khoz Inst 13, 281-285 (in Russian)

Louveaux J, Pourtallier MP, Vorwohl G (1973) Méthodes d'analyses des miels. Conductivité. Bull Apic 16, 7 p

Louveaux J, Maurizio A, Vorwohl G (1978) Methods of melissopalynology. Bee World 59, 139-157

Mohamed, MA, Ahmed AA, Mazid MM (1982) Studies on Libyan honey. J Food Quality 4, 185-201

Nikolopoulos C (1959) Melliferous flora of Attica. University of Athens, Athens, $117 p$ (in Greek)

Ough CS (1969) Rapid determination of proline in grapes and wines. J Food Sci 34, 228-230

Persano Oddo L, Piazza MG, Accorti M (1988) Diagnosis of unifloral honeys. I. Present knowledge and problems. Apicoltura 4, 1-11

Persano Oddo L, Baldi E, Accorti M (1990). Diastasic activity in some unifloral honeys. Apidologie 21, 17-24

Piazza MG, Accorti M, Persano Oddo L (1986) Indagine sulle caratteristiche chimico-fisiche dei mieli italiani di castagno e di melata. Apic Mod 77, 47-51

Piazza MG, Accorti M, Persano Oddo L (1991) Electrical conductivity, ash, colour and specific rotatory power in Italian unifloral honeys. Apicoltura 7, 51-63

Popescu N, Popa C, Popa A, Brinzac B (1965). Contribution à l'étude de la composition physico-chimique du miel provenant d'abeilles nourries au sirop de sucre. Bull Apic 8,139-146

Pourtallier J, Taliercio $Y(1970)$ Les caractéristiques physico-chimiques des miels en fonction de leur origine florale. I. Application à un projet de normes pour les grandes variétés de miels. Bull Apic 13, 58-68

Rodgers PEW (1979) Honey quality control. In: Honey, A Comprehensive Survey (E Crane, ed), Heinemann, London, 314-325

Rusakova TM (1984) The diastase number of honeys. Pchelovodstvo 10, $22-23$ (in Russian)

Sabatier S (1988) Les polyphénols des miels de tournesol. Congrès national des apiculteurs, Toulouse

Sancho MT, Muniategui S, Huidobro JF, Simal-Lozano $J$ (1991) Provincial classification of Basque country (northern Spain) honeys by their chemical composition. J Apic Res 30, 168-172

Santas LA, Bikos A (1979) The apicultural flora of Greece. Apiacta XIV, 115-123.

Santas LA (1983) Insects producing honeydew exploited by bees in Greece. Apidologie 14, 93-103

Sawyer R (1988) Honeydew. In: Honey ldentification, Cardiff Academic Press, 30-32

Schade JE, Marsh GL, Eckert JE (1958) Diastase activity and hydroxymethylfurfural in honey and their use- 
fulness in detecting heat alteration. Food Res 23 , 446-463

Serra Bonvehi J, Gomez Pajuelo A (1983) Chemical and physical characteristics of orange, rosemary and honeydews produced in Catalonia, Valence and Estremadura. XXIX ${ }^{\text {th }}$ Int Cong Apic Budapest, Hungary, Apimondia, 378-379

Serra Bonvehi J, Mundo Elias P (1988) A study of the pollen spectra of ling heather, Calluna vulgaris $\mathrm{L}$ (Hull), honeys produced in Spain. J Apic Res 27, 169-174

Serra Bonvehi J, Granados Tarrès E (1993) Physicochemical properties, composition and pollen spectrum of ling heather (Calluna vulgaris (L) Hull) honey produced in Spain. Apidologie 24, 586-596

Seijo MC, Aira MJ, Iglesias I, Jato MV (1992) Palynological characterization of honey from la Coruña province (NW Spain). J Apic Res 31, 149-155

Spettoli P, Bottacin A, Pescia P, Girolami V (1982) Caratteristiche fisico-chimiche di mieli di Erica arborea toscani. Ind Alim 21, 617-620

Stefanini R (1984). Variability and cluster analysis of Italian honeys. Apiacta XIX, 109-114

Talpay B (1985) Spezifikationen für Trachthonige. Deutsche Lebensmittel-Rundschau 81, 148-151

Thrasyvoulou A (1986) The use of HMF and diastase as criteria of quality of Greek honey. $J$ Apic Res 25, 186-195

Thrasyvoulou A, Bladenopoulou S (1984) A comparative analysis of Greek pine and blossom honey. $\mathrm{Nea}$ Melissa 2, 7-10 (in Greek)
Thrasyvoulou A, Manikis J (1993) The chemical composition of Greek honey 121-132. Proc National Conferences of Greece about Honey, Gerakini Chalkidiki (in Greek)

Varis AL, Helenius J, Koivulehto K (1982) Pollen spectrum of Finnish honey. J Sci Agric Soc Finland 54, 403-420

Vorwohl G (1964) Relations between the electrical conductivity of honeys and their botanical origin. Ann Abeille 7, 301-309

White JW, Riethof ML, Subers MH, Kushnir I (1962) Composition of American honeys. Tech Bull US Dept Agric 1261

White JW, Rudyj ON (1978) Proline content of United States honeys. J Apic Res 17, 89-93

White JW (1979) Composition of honey . In: Honey, A Comprehensive Survey (E Crane, ed), Heinemann, London, 157-206

White JW (1992) Quality evaluation of honey: role of HMF and diastase assays. Am Bee J 132, 737-743, 792-794

Wilson RB (1971) Diastase and hydroxymethylfurfural in international honey regulations. XXIII Int Apic Congr, Apimondia, 587-588

Zagaevskll IS, Kramarenko VV (1982) Criteria for differentiating between sugar-adulterated and natural honey. Voprosy Pitaniya 82, 63-65 (in Russian)

Zalewski W (1962) Determination of the activity of sugar splitting enzymes in local honeys. Pszczelarstwo 13, 67-69 (in Polish) 